\title{
Synthesis of Monobactam Antibiotic LYS228
}
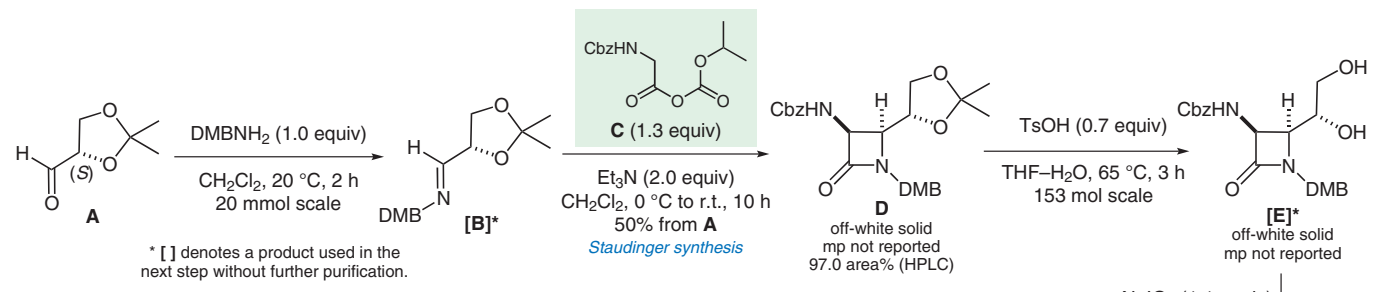

$\mathrm{NaIO}_{4}$ (1.1 equiv) EtOAc- $\mathrm{H}_{2} \mathrm{O}, 50^{\circ} \mathrm{C}, 2 \mathrm{~h}$
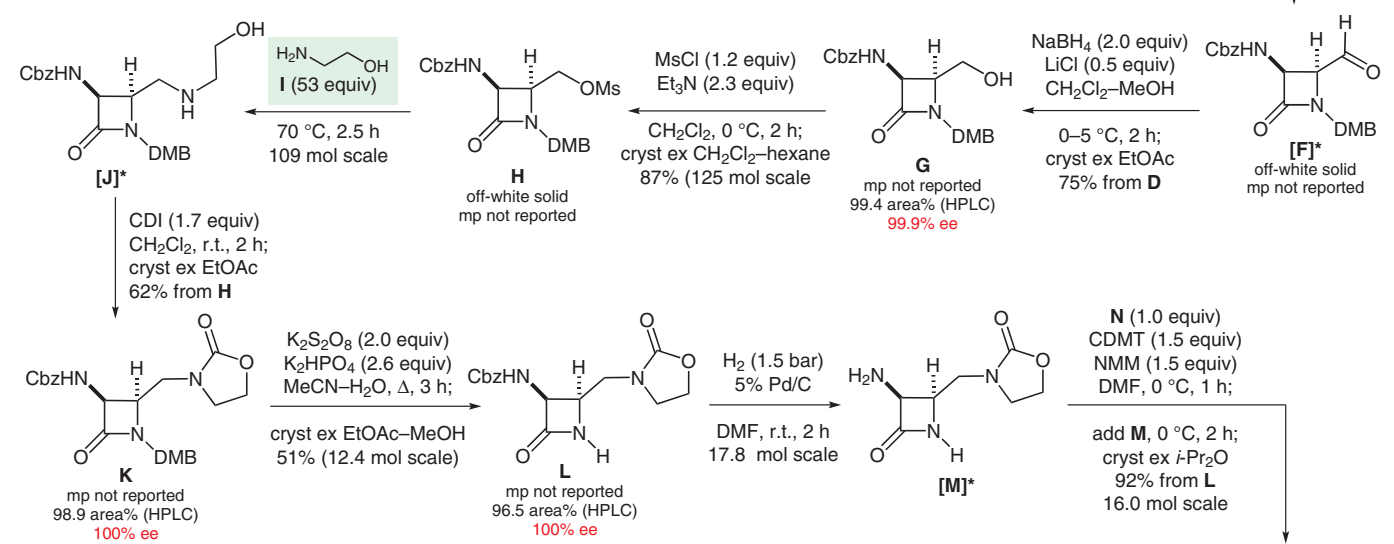

H
off-white solid
mp not reported

$\mathrm{CH}_{2} \mathrm{Cl}_{2}, 0^{\circ} \mathrm{C}, 2 \mathrm{~h} ;$
cryst ex $\mathrm{CH}_{2} \mathrm{Cl}_{2}$-hexan $87 \%$ (125 mol scale

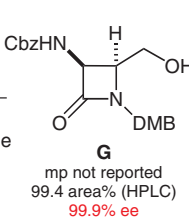

$\mathbf{N}$ (1.0 equiv)

CDMT (1.5 equiv)

NMM (1.5 equiv)

add $\mathbf{M}, 0{ }^{\circ} \mathrm{C}, 2 \mathrm{~h}$

cryst ex $i-\mathrm{Pr}_{2} \mathrm{O}$

$92 \%$ from $\mathrm{L}$

$16.0 \mathrm{~mol} \mathrm{scale}$

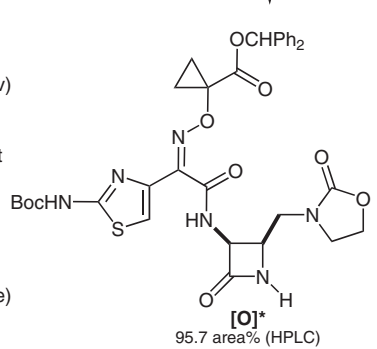

$\mathrm{DMF} \cdot \mathrm{SO}_{3}$ (3.8 equiv) DMF, $0^{\circ} \mathrm{C}, 3 \mathrm{~h}$; then $\mathrm{NaHCO}_{3}$
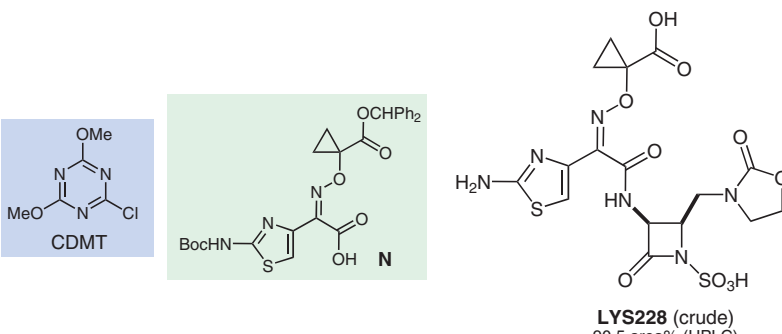

$93 \%$ of sodium salt $15.8 \mathrm{~mol} \mathrm{scale}$

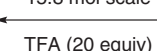

TFA (20 equiv) anisole (2.0 equiv) $81 \%$ (13.6 mol scale)

LYS228 (crude)
90.5 area\% (HPLC)

cryst ex THF- $\mathrm{H}_{2} \mathrm{O}$

$71 \%$ (10.9 mol scale)

LYS228.3 $3 \mathrm{H}_{2} \mathrm{O}$

97.8 area\% (HPLC)
Category

Synthesis of Natural

Products and

Potential Drugs

Key words

\section{LYS228}

monobactam antibiotic

asymmetric synthesis

[2+2] cycloaddition Staudinger $\beta$-lactam synthesis
Significance: LYS228 is a monobactam antibiotic that inhibits cell-wall synthesis in Gram-negative bacteria through covalent modification of the active-site serine of penicillin-binding protein 3. It is active in vitro and in vivo against Enterobacteriaceae, and it is stable to most serine- $\beta$-lactamases and all metallo- $\beta$-lactamases profiled to date.
Comment: The key step in the manufacturing process for LYS228 depicted is the asymmetric Staudinger $\beta$-lactam synthesis involving a $[2+2]$ cycloaddition of a ketene derived from $\mathrm{C}$ with aldimine $\mathbf{B}$ derived from (S)-glyceraldehyde acetonide $\mathbf{A}$ (C. Hubschwerlen, J.-L. Specklin Org. Synth. 1995, $72,14)$. For the discovery synthesis, see: Bioorg. Med. Chem. Lett. 2018, 28, 7748. 